\title{
COMPUTER SIMULATION OF TRANSIENT PROCESSES IN DFB SEMICONDUCTOR LASERS
}

\author{
T. Vasiliauskas ${ }^{\text {a }}$, V. Butkus ${ }^{\text {a }}$, E. Šermukšnis ${ }^{\text {b }}$, V. Palenskis ${ }^{\text {a }}$, and J. Vyšniauskas ${ }^{a}$ \\ ${ }^{a}$ Faculty of Physics, Vilnius University, Sauletekio 9, LT-10222 Vilnius, Lithuania \\ E-mail: tomas.vasiliauskas@ff.vu.lt, vytautas.butkus@ff.vu.lt, vilius.palenskis@ff.vu.lt,juozas.vysniauskas@ff.vu.lt \\ ${ }^{\mathrm{b}}$ Semiconductor Physics Institute, A. Goštauto 11, LT-01108 Vilnius, Lithuania \\ E-mail: emilis.sermuksnis@ff.vu.lt
}

Received 7 August 2007; revised 20 September 2007; accepted 21 November 2007

\begin{abstract}
Transient processes of semiconductor laser were simulated. These processes are best described by the variations of injected electron density and emitted photon density. Rate equations were chosen to describe the transient processes. Using the described model of transient processes, the unknown parameters of DFB (distributed feedback) semiconductor laser were defined from the experimental characteristics: the coefficient of optical amplification $\alpha$, the factor of spontaneous emission $\beta$, the electron and photon lifetime, and the form of injection current pulse. The parameter estimation technique, which allows to define laser parameter values simply, quickly, and fairly precisely, was suggested.

Transient processes were simulated for several DFB lasers and the coincidence of calculation results with experimental ones for all lasers was sufficient. The usable physical model was improved. Transient processes of lasers were simulated again and more precise results were obtained. The mismatch of analysed laser parameters with experimental ones did not exceed the limit of $10 \%$.
\end{abstract}

Keywords: simulation, transient processes, semiconductor lasers

PACS: $42.55 . P x$

\section{Introduction}

DFB semiconductor lasers are typical devices for information transmission in optical communication systems using direct modulation. These DFB lasers have stable frequency output, up to $\mathrm{Gb} / \mathrm{s}$ modulation rate, and uninterrupted operation time up to $10^{8}$ hours. Very strong attention to the design of these lasers and development of the production technologies is given. However, the communication system with the high-speed direct modulation is limited by transient processes due to interplay between the optical field and the carrier density. Thus, simulation of transient processes in DFB semiconductor lasers plays very important role. Transient processes usually are described by equations of electron and photon density changes (by rate equations) $[1,2]$.

Photon and electron density distributions were simulated using results of experiment and rate equations by changing values of laser parameters, such as lifetime of photons, coefficient of optical amplification, nonlinear amplification factor, spontaneous radiation and optical restriction factor, etc. The results of simulation were compared with experimental ones and the matching accuracy was calculated.

\section{Theoretical models}

In this work four physical models were used. At first, a simplified physical model based on rate equations for carrier and photon densities was used for computer simulation [1]. However, though some of physical factors were not included in this model, the accuracy of modelling results for some DFB lasers was sufficiently good. In the later models, the rate equations were supplemented with additional physical parameters.

For the second physical model the nonlinear amplification factor $\varepsilon$ was included in the rate equations. Optical amplification coefficient $\alpha\left[\mathrm{cm}^{3} / \mathrm{s}\right]$ was assumed to be equal to the product of the optical differential amplification $g\left[\mathrm{~cm}^{2}\right]$ and the group velocity $v_{\mathrm{g}}\left(\alpha=v_{\mathrm{g}} g\right)$ in the earlier model of simplified rate equations [1]. Also, the optical amplification depends on photon density:

$$
g(N, P)=g_{0}(1-\varepsilon P)=g\left(N-N_{\mathrm{ot}}\right)(1-\varepsilon P),
$$


where $N$ is the density of electrons, $P$ is the density of photons, $N_{0}$ is the density of electrons needed for reaching Fermi quasi level, and $\varepsilon$ is the nonlinear amplification factor.

Then the term of number of photons generated by spontaneous emission in the rate equations was supplemented with factor $(1-\varepsilon P)$.

In the third model, the term $N / \tau_{\mathrm{s}}$ in the rate equation [1] is changed to $N \gamma_{\mathrm{e}}(N)$, because $\gamma_{\mathrm{e}}=1 / \tau_{\mathrm{s}}$, where $\gamma_{\mathrm{e}}(N)$ is the rate of electron recombination [2]:

$$
\gamma_{\mathrm{e}}(N)=A+B N+C N^{2},
$$

where the first term $A$ of equation describes nonradiative recombination, $B$ is the coefficient of radiant interband recombination, and $C$ is the coefficient of Auger recombination. The carrier lifetime $\tau_{\mathrm{s}}$ can be described by these parameters in such a way:

$$
\tau_{\mathrm{s}}(N)=\left(A+B N+C N^{2}\right)^{-1},
$$

and can be used in the rate equations (4).

In the fourth model, we used such rate equation for electron density [2]:

$$
\begin{array}{r}
\frac{\mathrm{d} N}{\mathrm{~d} t}=\frac{J}{e d}-N\left(A+B N+C N^{2}\right) \\
-\alpha\left(N-N_{0}\right)(1-\varepsilon P) P,
\end{array}
$$

where $J$ is the density of injection current, $e$ is the electron charge, $d$ is the width of semiconductor laser active region, $t$ is the time. The first term of the rate equation (4) describes the number of injected carriers that pass the unit volume per unit time interval, the second one describes the spontaneous emission, and the third term defines the number of photons generated by stimulated emission per unit time interval. An analogous equation was used for photon density:

$$
\frac{\mathrm{d} P}{\mathrm{~d} t}=\Gamma \alpha\left(N-N_{0}\right)(1-\varepsilon P) P-\frac{P}{\tau_{\mathrm{p}}}+\Gamma \beta B N^{2},
$$

where $\tau_{\mathrm{p}}$ is the lifetime of photons, $\beta$ is the spontaneous emission factor, $\Gamma$ is the optical confinement factor. The first term of the rate equation (5) is the number of photons generated by stimulated emission per unit time interval, the second term is the number of photons emitted from resonator (output of the laser). The third term of Eq. (5) shows the spontaneous emission contribution to generated mode.

\section{Used experimental results}

Experimental results of DFB semiconductor lasers were used for computer simulation. Not all laser parameters needed for simulation were known and some parameters were estimated from experimental results. Product of photon and electron lifetimes, threshold current, and current at the $5 \mathrm{~mW}$ average optical power were known. Extinction ratio (ratio of the of optical power level " 1 " to the level " 0 ") was equal to $8.5 \mathrm{~dB}$ :

$$
10 \lg \frac{P_{1}}{P_{0}}=8.5 \text {. }
$$

Injection current values at levels "0" and "1" were found from optical power dependence on injected current by using condition (6) for optical power $5 \mathrm{~mW}$. The active region width was estimated from the TEM image. We also had a possibility to calculate the injection current density from current measurements.

Experimentally obtained parameters of semiconductor DFB laser and those used for calculations were:

- product of lifetimes, $\tau_{\mathrm{s}} \tau_{\mathrm{p}}$ (different for each laser, see Table 1);

- threshold current, $I_{\text {th }}$ (different for each laser, see Table 1);

- mean current (current when average optical power is equal to $5 \mathrm{~mW}$ ), $I_{\mathrm{op}}$ (different for each laser, see Table 1);

- optical powers $P_{1}=8.59 \mathrm{~mW}, P_{0}=1.41 \mathrm{~mW}$ (the same for all lasers);

- injection currents $I_{1}$ (level "1") and $I_{0}$ (level "0") found from optical power dependence on injected current (see Fig. 1);

- dimensions of the active region of the DFB laser, $L=300 \mu \mathrm{m}$ (channel length), $w=1.5 \mu \mathrm{m}$ (width), $d=0.1 \mu \mathrm{m}$ (thickness), $S=L \cdot w=4.5 \cdot 10^{-6} \mathrm{~cm}^{2}$ (area) (the same for all lasers);

- injection current density (calculated by using active region dimensions, see Table 1);

- experimental pulse characteristics: optical power and chirp (different for each laser).

\section{Simulation results}

Computer simulation was based on fourth-order Runge-Kutta method for the system of differential equations. The values of photon and electron densities 
Table 1. Experimental results used in simulation.

\begin{tabular}{rccccccc}
\hline No. & DFB laser & $\tau_{\mathrm{s}} \tau_{\mathrm{p}}\left[\mathrm{s}^{2}\right]$ & $I_{\mathrm{th}}[\mathrm{mA}]$ & $I_{\mathrm{op}}[\mathrm{mA}]$ & $J_{\mathrm{th}}\left[\mathrm{A} / \mathrm{cm}^{2}\right]$ & $J_{1}\left[\mathrm{~A} / \mathrm{cm}^{2}\right]$ & $J_{0}\left[\mathrm{~A} / \mathrm{cm}^{2}\right]$ \\
\hline 1 & O6j5 & $1.91 \cdot 10^{-20}$ & 12.31 & 33.09 & 2736 & 10711 & 4066 \\
2 & $\mathrm{H} 3 \mathrm{k} 7$ & $1.63 \cdot 10^{-20}$ & 11.56 & 33.07 & 2569 & 10756 & 3958 \\
3 & $\mathrm{G} 3 \mathrm{k} 4$ & $1.64 \cdot 10^{-20}$ & 11.89 & 32.94 & 2642 & 10638 & 3982 \\
4 & $\mathrm{~J} 5 \mathrm{k} 7$ & $1.65 \cdot 10^{-20}$ & 11.15 & 34.26 & 2478 & 11300 & 3927 \\
5 & $\mathrm{U} 2 \mathrm{i} 3$ & $2.26 \cdot 10^{-20}$ & 8.19 & 30.10 & 1820 & 10184 & 3282 \\
6 & $\mathrm{R} 4 \mathrm{j} 5$ & $1.72 \cdot 10^{-20}$ & 11.29 & 32.33 & 2509 & 10542 & 3827 \\
7 & $\mathrm{E} 3 \mathrm{k} 4$ & $1.68 \cdot 10^{-20}$ & 11.36 & 34.38 & 2524 & 11313 & 3967 \\
8 & $\mathrm{~F} 2 \mathrm{k} 7$ & $1.69 \cdot 10^{-20}$ & 11.03 & 35.17 & 2451 & 11667 & 3964 \\
9 & $\mathrm{G} 111$ & $1.60 \cdot 10^{-20}$ & 11.74 & 32.80 & 2609 & 10649 & 3929 \\
10 & $\mathrm{P} 5 \mathrm{i} 3$ & $2.12 \cdot 10^{-20}$ & 8.72 & 30.65 & 1938 & 10309 & 3311 \\
11 & $\mathrm{~T} 2 \mathrm{~s} 2$ & $2.06 \cdot 10^{-20}$ & 8.85 & 31.46 & 1967 & 10767 & 3449 \\
12 & $\mathrm{~S} 2 \mathrm{i} 3$ & $2.37 \cdot 10^{-20}$ & 8.09 & 28.94 & 1798 & 9758 & 3104 \\
13 & $\mathrm{R} 2 \mathrm{r} 3$ & $1.72 \cdot 10^{-20}$ & 11.44 & 35.80 & 2542 & 11842 & 4069 \\
14 & $\mathrm{~T} 2 \mathrm{i} 3$ & $2.25 \cdot 10^{-20}$ & 8.02 & 31.63 & 1782 & 10796 & 3262 \\
15 & $\mathrm{Q} 1 \mathrm{t} 1$ & $1.62 \cdot 10^{-20}$ & 11.12 & 36.82 & 2471 & 12282 & 4082 \\
16 & $\mathrm{O} 1 \mathrm{k} 1$ & $1.63 \cdot 10^{-20}$ & 10.50 & 35.32 & 2333 & 11809 & 3871 \\
17 & O2s2 & $1.99 \cdot 10^{-20}$ & 8.74 & 32.34 & 1942 & 10951 & 3389 \\
\hline
\end{tabular}

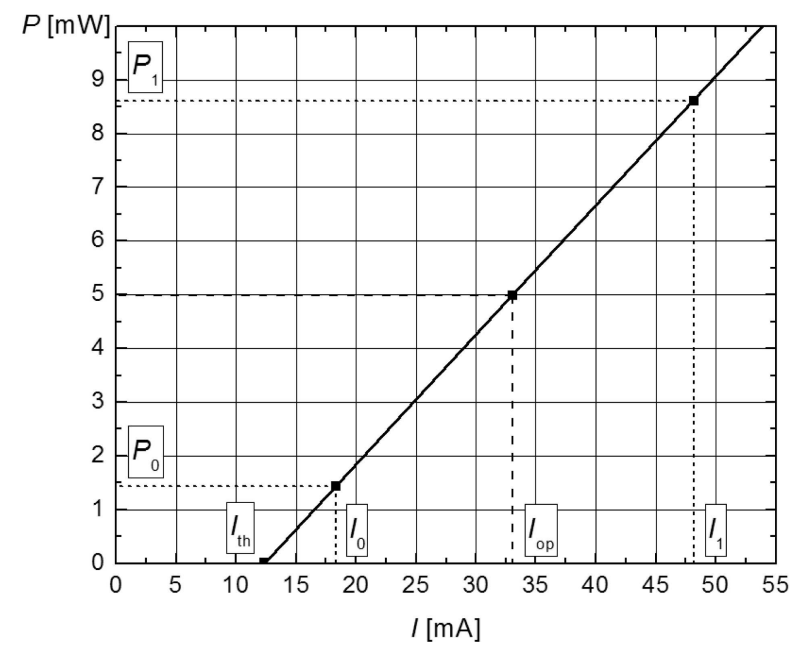

Fig. 1. Optical power dependence on injection current.

for different time moments were found from initial values of densities, by setting other parameters and choosing time step and number of calculations loops.

In the computer simulation the following unknown parameters were selected: the optical confinement factor $\Gamma$, the reflection coefficients from mirrors at the ends, $R_{1}$ and $R_{2}$ [3], the lifetime of photons $\tau_{\mathrm{p}}$, the coefficient of optical amplification $\alpha$, the spontaneous emission factor $\beta$, the density of electrons needed for reaching Fermi quasi-level $N_{0}$, the nonlinear amplification factor $\varepsilon$, and the coefficients of recombination $A, B$, and $C$.

The investigation of laser parameters interplay was done. On the grounds of obtained simulation results, the following technique for estimation of semiconductor laser parameters was suggested:
- the frequency of relaxation oscillation is defined by changing the coefficient of optical amplification $\alpha$;

- the calculated optical power values are made close to experimental ones by changing optical confinement factor $\Gamma$;

- by changing the nonlinear amplification factor $\varepsilon$ and spontaneous emission factor $\beta$, the relaxation oscillation amplitudes can be corrected; additionally, the shape of oscillations also can be corrected by changing the injection current front duration;

- the recombination coefficient $A$ and the density of electrons needed for reaching Fermi quasi-level $N_{0}$ is changed to optimize the static characteristics of semiconductor laser;

- the recombination coefficients $B$ and $C$ are chosen at last. These coefficients have insignificant influence on laser dynamics, they only change a little the shape of oscillations.

Calculations for model verification were done, investigation of watt-ampere characteristic being one of them (see Fig. 2). The threshold current was found as well. Obtained results were also compared to those of other authors [4].

The output optical power of semiconductor laser was calculated by using such equations [4]:

$$
\begin{aligned}
P_{1}= & \frac{h c^{2}}{\lambda \mu_{\mathrm{g}}} \frac{1}{2 L} \log \frac{1}{R_{1} R_{2}} L d w n_{\mathrm{ph}} \\
& \times \frac{\left(1-R_{1}\right) R_{2}^{1 / 2}}{\left(R_{1}^{1 / 2}+R_{2}^{1 / 2}\right)\left(1-R_{1}^{1 / 2} R_{2}^{1 / 2}\right)},
\end{aligned}
$$




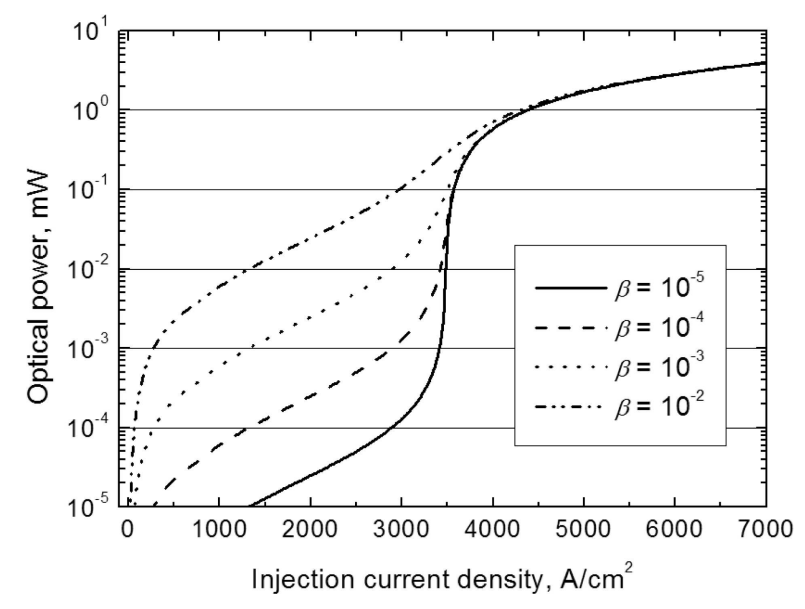

Fig. 2. Watt-ampere characteristics of $1.3 \mu \mathrm{m}$ laser diode near the threshold of injection current for different spontaneous emission factors $\beta$.

$$
\begin{aligned}
P_{2}= & \frac{h c^{2}}{\lambda \mu_{\mathrm{g}}} \frac{1}{2 L} \log \frac{1}{R_{1} R_{2}} L d w n_{\mathrm{ph}} \\
& \times \frac{\left(1-R_{2}\right) R_{1}^{1 / 2}}{\left(R_{1}^{1 / 2}+R_{2}^{1 / 2}\right)\left(1-R_{1}^{1 / 2} R_{2}^{1 / 2}\right)},
\end{aligned}
$$

where $R_{1}$ and $R_{2}$ are the reflection coefficients of end mirrors, $h$ is the Planck's constant, $c$ is speed of light, $\lambda$ is wavelength of radiated light, $\mu_{\mathrm{g}}$ is group refraction index, $L$ is length of laser active region, $d$ is thickness of active region, $w$ is the active region width, and $n_{\mathrm{ph}}$ is density of photons.

The best results were obtained based on the fourth physical model, Eqs. (4) and (5). The best match of experiment and simulation results for all investigated lasers with different characteristics was obtained. The mismatch of analysed laser parameters does not exceed the limit of $10 \%$.

The most precise match of laser characteristics was obtained for the laser O6j5 with chirp and density of electrons shown in Fig. 3 (the chirp is proportional to the carrier density [5]) and optical power pulse characteristic shown in Fig. 4.

Selected values for matching of unknown parameters were: $\Gamma=0.55, R_{1}=0.04, R_{2}=0.664, \tau_{\mathrm{p}}=$ $1.5 \cdot 10^{-12} \mathrm{~s}, \alpha=16.8 \cdot 10^{-7} \mathrm{~cm}^{3} / \mathrm{s}, \beta=1 \cdot 10^{-4}, N_{\mathrm{ot}}=$ $24.3 \cdot 10^{17} \mathrm{~cm}^{-3}, \varepsilon=9.5 \cdot 10^{-18}, \tau_{\mathrm{j} 1}=54 \cdot 10^{-12} \mathrm{~s}, \tau_{\mathrm{j} 2}=$ $50 \cdot 10^{-12} \mathrm{~s}, A=2.5 \cdot 10^{8} \mathrm{~cm} / \mathrm{s}, B=9.1 \cdot 10^{-12} \mathrm{~cm}^{3} / \mathrm{s}$, $C=3.80 \cdot 10^{-29} \mathrm{~cm}^{6} / \mathrm{s}$.

The values of parameters for other lasers and comparison of simulation and experiment results are presented in Tables 1 and 2. In order to evaluate the accuracy of simulation results, the parameters like frequency $(\nu)$ of relaxation oscillations, time of oscilla-

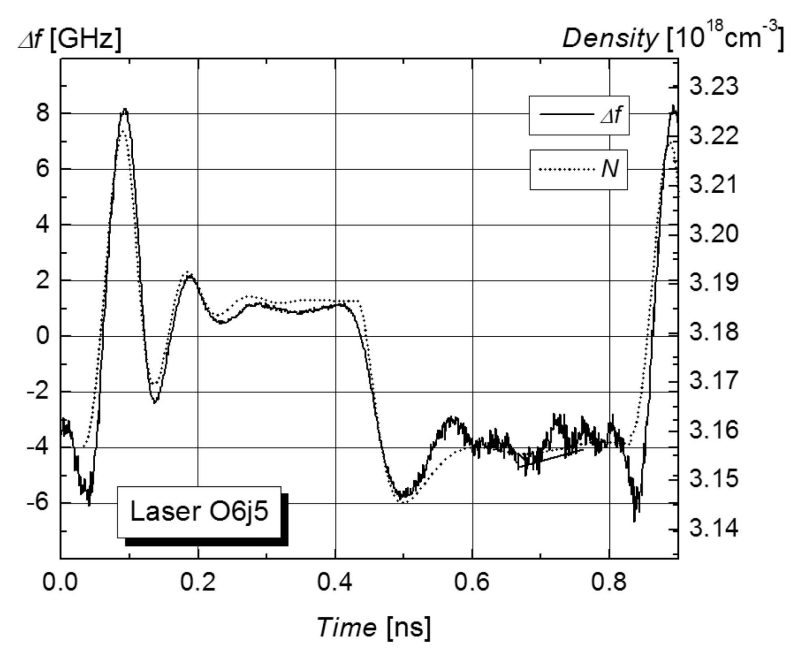

Fig. 3. Simulated electron density $(N)$ and experimental chirp $(\Delta f)$ pulse characteristics.

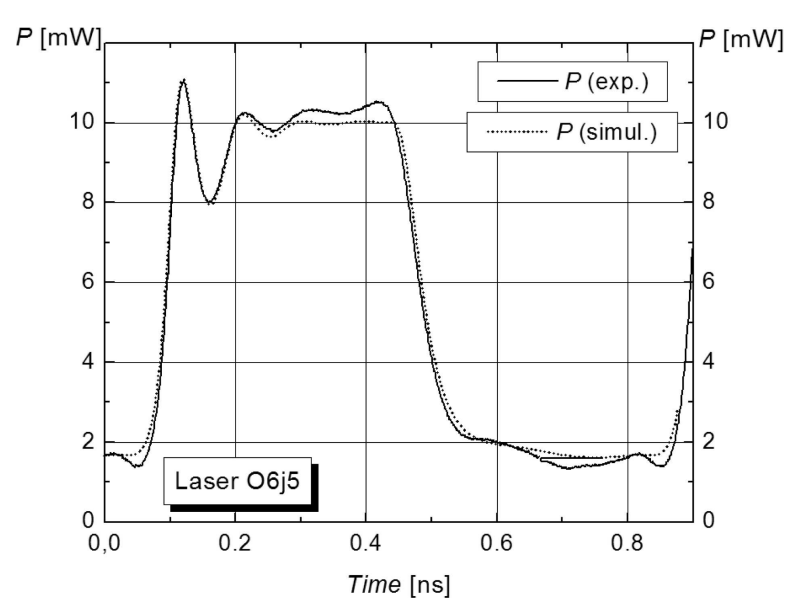

Fig. 4. Experimental and simulated pulse characteristics of optical power $P$.

tion decrement $(T)$, "1" and " 2 " levels proportion $(l)$, and the proportion of amplitude of first peak and level "1" (a) were compared (see Table 3). The averaged value of mismatch $(M)$ between the simulation and experimental results for these parameters was calculated (see Fig. 5).

\section{Conclusions}

In this work the transient characteristics of semiconductor lasers were investigated; by using computer simulation, the unknown laser parameters that were not measured in experiment were obtained. On the grounds of these simulation results the parameter estimation technique was suggested. The rate equations used for computer simulation were improved (comparing with earlier simulation [1]) by including the nonlinear amplification factor $\varepsilon$, the optical confinement 

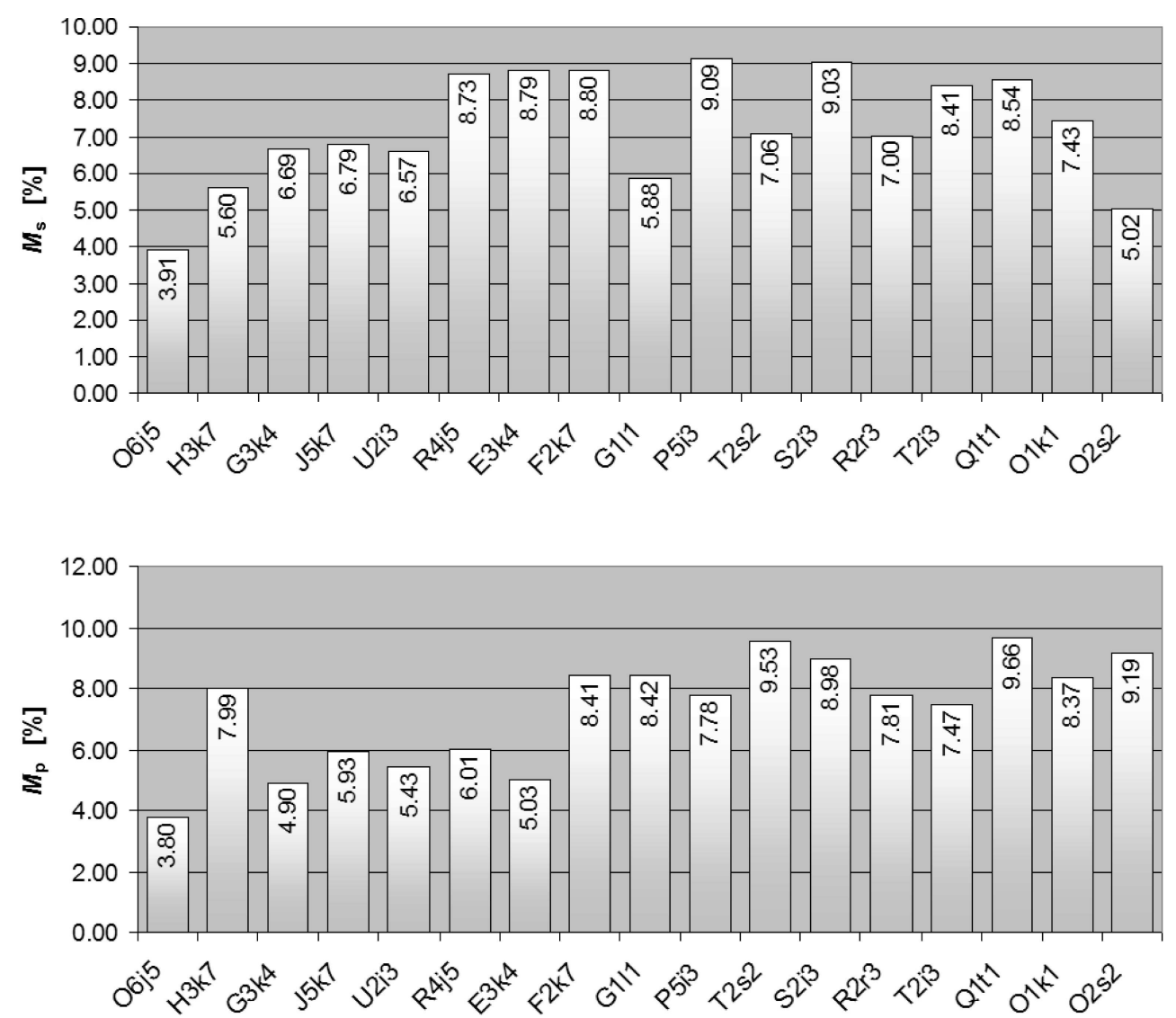

Fig. 5. Averaged value of mismatch of simulated laser parameters for different lasers: $M_{\mathrm{s}}$ is for electron density characteristic, $M_{\mathrm{p}}$ is for optical power characteristic.

Table 2. Fourth model: computer simulation results.

\begin{tabular}{|c|c|c|c|c|c|c|c|c|c|c|c|c|c|c|}
\hline No. & $\begin{array}{l}\text { DFB } \\
\text { laser }\end{array}$ & $\Gamma$ & $R_{1}$ & $R_{2}$ & $\begin{array}{c}\tau_{\mathrm{p}} \\
{[\mathrm{ps}]}\end{array}$ & $\begin{array}{c}\alpha \\
{\left[\mathrm{cm}^{3} / \mathrm{s}\right]}\end{array}$ & $\beta$ & $\begin{array}{c}N_{\mathrm{ot}} \\
{\left[\mathrm{cm}^{-3}\right]}\end{array}$ & $\varepsilon$ & $\begin{array}{c}\tau_{\mathrm{j} 1} \\
{[\mathrm{ps}]}\end{array}$ & $\begin{array}{l}\tau_{\mathrm{j} 2} \\
{[\mathrm{ps}]}\end{array}$ & $\begin{array}{c}A \\
{[\mathrm{~cm} / \mathrm{s}]}\end{array}$ & $\begin{array}{c}B \\
{\left[\mathrm{~cm}^{3} / \mathrm{s}\right]}\end{array}$ & $\begin{array}{c}C \\
{\left[\mathrm{~cm}^{6} / \mathrm{s}\right]}\end{array}$ \\
\hline 1 & & 0.55 & 04 & 0.664 & & -7 & 10 & $9^{17}$ & $9.5 \cdot 10^{-}$ & 54 & 50 & 8 & $9.1 \cdot 10^{-12}$ & J \\
\hline 2 & 7 & & 8 & & 2.0 & & & $27.0 \cdot 10^{17}$ & 列 & & & & -12 & -29 \\
\hline 3 & G3k4 & 49 & .08 & 0.80 & 2.0 & $6 \cdot 10^{-7}$ & 3 & $27.0 \cdot 10^{17}$ & $11 \cdot 10^{-18}$ & 56 & 53 & $2.8 \cdot 10^{8}$ & $8.4 \cdot 10^{-12}$ & $3.25 \cdot 10^{-29}$ \\
\hline 4 & $\mathrm{~J} 5 \mathrm{k} 7$ & .33 & 0.08 & 0.80 & 3.0 & $6 \cdot 10^{-7}$ & $1 \cdot 10^{-3}$ & $26.0 \cdot 10^{17}$ & $15 \cdot 10$ & 50 & 5 & $3.6 \cdot 10^{8}$ & $4.7 \cdot 10^{-12}$ & $2.44 \cdot 10^{-29}$ \\
\hline 5 & $\mathrm{U} 2 \mathrm{i} 3$ & 0.37 & 0.08 & 0.80 & 2.0 & & $1 \cdot 10^{-4}$ & $14.0 \cdot 10^{17}$ & $17 \cdot 10^{-18}$ & 66 & 66 & $4.1 \cdot 10^{8}$ & $5.5 \cdot 10^{-12}$ & $4.00 \cdot 10^{-29}$ \\
\hline 6 & $\mathrm{R} 4 \mathrm{j} 5$ & 0.67 & 0.08 & 0.80 & 1.8 & -7 & $1 \cdot 10^{-2}$ & $25.0 \cdot 10^{17}$ & $16 \cdot 10^{-18}$ & 55 & 5 & $4.8 \cdot 10^{8}$ & $9.6 \cdot 10^{-12}$ & $3.00 \cdot 10^{-29}$ \\
\hline 7 & E3k4 & 0.32 & 0.08 & 0.80 & 3.4 & & $1 \cdot 10^{-3}$ & $27.0 \cdot 10^{17}$ & $19 \cdot 1$ & 75 & 6 & 5.0 . & )$^{-12}$ & $2.00 \cdot 10^{-29}$ \\
\hline 8 & F2k7 & 0.43 & 0.08 & 0.80 & 2.5 & 7 & $1 \cdot 1$ & 29.0 . & $16 \cdot 1$ & 50 & 40 & $4.0 \cdot 10^{8}$ & $5.0 \cdot 10^{-12}$ & $1.00 \cdot 10^{-29}$ \\
\hline 9 & G111 & 0.42 & 0.08 & 0.8 & 3.0 & -7 & $1 \cdot 10^{-2}$ & $28.0 \cdot 10^{17}$ & $14 \cdot 10^{-18}$ & 60 & 40 & $2.0 \cdot 10^{8}$ & $3.0 \cdot 10^{-12}$ & $4.00 \cdot 10^{-29}$ \\
\hline 10 & $\mathrm{P} 5 \mathrm{i} 3$ & 0.61 & 0.08 & 0.80 & 2.0 & $10^{-7}$ & $1 \cdot 10^{-2}$ & $23.0 \cdot 10^{17}$ & $15 \cdot 10^{-18}$ & 60 & 5( & $3.0 \cdot 10^{8}$ & $2.0 \cdot 10^{-12}$ & $4.00 \cdot 10^{-29}$ \\
\hline 11 & $\mathrm{~T} 2 \mathrm{~s} 2$ & 0 & 0.08 & 0.8 & 1.5 & & & $19.0 \cdot 10^{17}$ & $14 \cdot 10^{-18}$ & 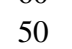 & 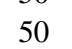 & & $3.0 \cdot 10^{-12}$ & $4.00 \cdot 10^{-29}$ \\
\hline 12 & $\mathrm{~S} 2 \mathrm{i} 3$ & 0.3 & 0.08 & 0.80 & 1.9 & & $1 \cdot 10$ & $17.0 \cdot 1$ & 18 & 60 & 5 & & $7.0 \cdot 10^{-12}$ & $3.00 \cdot 10^{-29}$ \\
\hline 13 & $\mathrm{R} 2 \mathrm{r} 3$ & 0.66 & 0.08 & 0.8 & 2.1 & -7 & $1 \cdot 10^{-3}$ & $24.0 \cdot 10^{17}$ & $11 \cdot 10^{-18}$ & 50 & 5 & $4.0 \cdot 10^{8}$ & $5.0 \cdot 10^{-12}$ & $4.00 \cdot 10^{-29}$ \\
\hline 14 & $\mathrm{~T} 2 \mathrm{i} 3$ & 0.41 & 0.08 & 0.80 & 2.0 & $29.0 \cdot 10^{-7}$ & $1 \cdot 10^{-2}$ & $15.0 \cdot 10^{17}$ & $17 \cdot 10^{-18}$ & 65 & 45 & $4.9 \cdot 10^{8}$ & $1.0 \cdot 10^{-12}$ & $4.50 \cdot 10^{-29}$ \\
\hline 15 & Q1t1 & 0.3 & 0.0 & 0 & 2.3 & & $1 \cdot 10^{-2}$ & & $19 \cdot 10^{-18}$ & 50 & 4 & & $3.0 \cdot 10^{-12}$ & $4.00 \cdot 10^{-29}$ \\
\hline 16 & O1k1 & 0.4 & 0.08 & 0.80 & 2.5 & & & $29.0 \cdot 1$ & & 50 & 45 & & & $2.00 \cdot 10^{-29}$ \\
\hline 17 & $\mathrm{O} 2 \mathrm{~s} 2$ & 0.35 & 0.08 & 0.80 & 1.9 & $28.0 \cdot 10^{-7}$ & $1 \cdot 10^{-3}$ & $28.0 \cdot 10^{17}$ & $19 \cdot 10^{-18}$ & 50 & 45 & $2.0 \cdot 10^{8}$ & $4.0 \cdot 10^{-12}$ & $2.00 \cdot 10^{-29}$ \\
\hline
\end{tabular}


Table 3. Mismatch (\%) of simulation data and experimental results.

\begin{tabular}{rccccccccccc}
\hline \multirow{2}{*}{ No. } & DFB & & \multicolumn{8}{c}{ Mismatch of simulation parameters [\%] } \\
& laser & $\nu_{\mathrm{s}}$ & $\nu_{\mathrm{p}}$ & $T_{\mathrm{s}}$ & $T_{\mathrm{p}}$ & $l_{\mathrm{s}}$ & $l_{\mathrm{p}}$ & $a_{\mathrm{s}}$ & $a_{\mathrm{p}}$ & $M_{\mathrm{s}}$ & $M_{\mathrm{p}}$ \\
\hline 1 & O6j5 & 2.33 & 2.02 & 8.60 & 7.43 & 1.33 & 4.85 & 3.39 & 0.90 & 3.91 & 3.80 \\
2 & H3k7 & 1.35 & 7.44 & 9.72 & 9.90 & 9.61 & 7.33 & 1.74 & 7.29 & 5.60 & 7.99 \\
3 & G3k4 & 1.49 & 5.38 & 9.84 & 8.22 & 9.36 & 4.08 & 6.04 & 1.92 & 6.69 & 4.90 \\
4 & J5k7 & 2.14 & 9.98 & 9.97 & 8.25 & 8.37 & 4.50 & 6.67 & 0.98 & 6.79 & 5.93 \\
5 & U2i3 & 0.90 & 4.81 & 9.75 & 9.84 & 9.62 & 3.94 & 6.02 & 3.12 & 6.57 & 5.43 \\
6 & R4j5 & 9.32 & 6.56 & 9.84 & 9.21 & 6.40 & 6.20 & 9.35 & 2.08 & 8.73 & 6.01 \\
7 & E3k4 & 5.51 & 4.96 & 9.87 & 9.76 & 9.85 & 2.19 & 9.93 & 3.19 & 8.79 & 5.03 \\
8 & F2k7 & 9.98 & 9.71 & 9.90 & 4.65 & 9.34 & 9.92 & 5.97 & 9.35 & 8.80 & 8.41 \\
9 & G111 & 3.43 & 8.01 & 9.78 & 9.97 & 1.59 & 8.96 & 8.72 & 6.74 & 5.88 & 8.42 \\
10 & P5i3 & 6.59 & 9.89 & 9.97 & 9.68 & 9.89 & 4.57 & 9.93 & 6.98 & 9.09 & 7.78 \\
11 & T2s2 & 9.82 & 9.33 & 9.43 & 9.71 & 2.89 & 9.83 & 6.11 & 9.26 & 7.06 & 9.53 \\
12 & S2i3 & 8.07 & 7.97 & 9.51 & 9.75 & 9.09 & 8.92 & 9.43 & 9.28 & 9.03 & 8.98 \\
13 & R2r3 & 9.96 & 9.91 & 6.64 & 8.74 & 1.79 & 3.59 & 9.62 & 8.99 & 7.00 & 7.81 \\
14 & T2i3 & 9.65 & 9.82 & 8.60 & 9.09 & 9.63 & 6.67 & 5.77 & 4.30 & 8.41 & 7.47 \\
15 & Q1t1 & 9.55 & 9.93 & 9.74 & 9.87 & 4.95 & 9.86 & 9.93 & 8.99 & 8.54 & 9.66 \\
16 & O1k1 & 8.46 & 9.83 & 9.12 & 9.78 & 9.80 & 4.36 & 2.34 & 9.52 & 7.43 & 8.37 \\
17 & O2s2 & 3.88 & 9.81 & 9.71 & 8.31 & 4.40 & 9.54 & 2.10 & 9.09 & 5.02 & 9.19 \\
\hline
\end{tabular}

factor $\Gamma$, and changing the carrier lifetime $\tau_{\mathrm{s}}$ by the way of (3), which describes nonradiative recombination, radiative interband recombination, and Auger recombination. Transient processes were simulated for large number of similar DFB lasers. The best results were obtained by using the fourth physical model. The mismatch between the simulation and experimental results for all analysed laser parameters in this case did not exceed the limit of $10 \%$.

\section{References}

[1] E. Šermukšnis, J. Vyšniauskas, T. Vasiliauskas, and V. Palenskis, Computer simulation of high frequency modulation of laser diode radiation, Lithuanian J. Phys. 44(6), 415 (2004).

[2] D.G. Haigh, R.S. Soin, and J. Wood, Distributed Feedback Semiconductors Lasers (IEE, London, 1998).

[3] M. Fukuda, Optical Semiconductor Devices (John Wiley \& Sons, New York, 1999).

[4] G.P. Agrawal and N.K. Dutta, Semiconductor Lasers, 2nd ed. (Van Nostrand Reinhold, New York, 1993).

[5] C.H. Henry, Theory of the line width of semiconductor lasers, IEEE J. Quantum Electron. QE-18(2), 259 (1982).

\title{
PEREINAMŲUU VYKSMŲ PUSLAIDININKINIUOSE PASKIRSTYTOJO GRIŽTAMOJO RYŠIO LAZERIUOSE MODELIAVIMAS
}

\author{
T. Vasiliauskas ${ }^{\text {a }}$, V. Butkus ${ }^{\text {a }}$, E. Šermukšnis ${ }^{b}$, V. Palenskis ${ }^{\text {a }}$, J. Vyšniauskas ${ }^{\text {a }}$

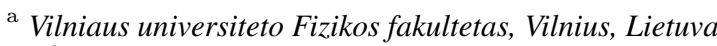 \\ b Puslaidininkiu fizikos institutas, Vilnius, Lietuva
}

\section{Santrauka}

Ištirtos puslaidininkinių PGR (paskirstytojo grižtamojo ryšio) lazeriu charakteristikos, išmatuoti tam tikri lazerio parametrai, o kompiuterinio modeliavimo būdu surasti nežinomi parametrai, kurių nebuvo galima išmatuoti eksperimento metu. Ištirtos puslaidininkinio lazerio parametrų tarpusavio priklausomybès, remiantis gautais rezultatais, parengta jo parametrų nustatymo metodika.
Patikslintos kompiuteriniam modeliavimui vartojamos spartos lygtys, iskaitant narius, kurie nebuvo vartojami ankstesniuose skaičiavimuose [1]. Ivertinti modeliavimo ir eksperimentinių rezultatų nesutapimo skirtumai. Geriausias rezultatų sutapimas visiems to paties tipo tirtiems puslaidininkiniams lazeriams, nors ir turintiems šiek tiek skirtingas charakteristikas, gautas naudojantis pasiūlytu ketvirtuoju modeliu (lygtys (4) ir (5)). Šiuo atveju rezultatų nesutapimas neviršijo $10 \%$. 